\title{
High Precision Zinc Stable Isotope Measurement of Certified Biological Reference Materials Using the Double Spike Technique and Multiple Collector-ICP-MS
}

\author{
Rebekah E. T. Moore ${ }^{1} \cdot$ Fiona Larner ${ }^{2} \cdot$ Barry J. Coles $^{1} \cdot$ Mark Rehkämper $^{1}$
}

Received: 29 September 2016 / Revised: 9 January 2017 / Accepted: 2 February 2017 / Published online: 16 February 2017

(C) The Author(s) 2017. This article is published with open access at Springerlink.com

\begin{abstract}
Biological reference materials with wellcharacterised stable isotope compositions are lacking in the field of 'isotope biochemistry', which seeks to understand bodily processes that rely on essential metals by determining metal stable isotope ratios. Here, we present $\mathrm{Zn}$ stable isotope data for six biological reference materials with certified trace metal concentrations: fish muscle, bovine muscle, pig kidney, human hair, human blood serum and human urine. Replicate analyses of multiple aliquots of each material achieved reproducibilities (2sd) of $0.04-0.13 \%$ of $\delta^{66 / 64} \mathrm{Zn}$ (which denotes the deviation of the ${ }^{66} \mathrm{Zn} /{ }^{64} \mathrm{Zn}$ ratio of a sample from a pure $\mathrm{Zn}$ reference material in parts per 1000). This implies only very minor isotopic heterogeneities within the samples, rendering them suitable as quality control materials for $\mathrm{Zn}$ isotope analyses. This endorsement is reinforced by (i) the close agreement of our $\mathrm{Zn}$ isotope data for two of the samples (bovine muscle and human blood serum) to previously published results for different batches of the same material and (ii) the similarity of the isotopic data for the samples $\left(\delta^{66 / 64} \mathrm{Zn} \approx-\right.$ 0.8 to $0.0 \%$ ) to previously published $\mathrm{Zn}$ isotope results for similar biological materials. Further tests revealed that the applied $\mathrm{Zn}$ separation procedure is sufficiently effective to
\end{abstract}

Electronic supplementary material The online version of this article (doi:10.1007/s00216-017-0240-y) contains supplementary material, which is available to authorized users.

Rebekah E. T. Moore

r.moore13@imperial.ac.uk

1 Department of Earth Science and Engineering, Imperial College London, Royal School of Mines, Prince Consort Rd, Kensington London SW7 2AZ, UK

2 Department of Earth Sciences, University of Oxford, South Parks Road, Oxford OX1 3AN, UK enable accurate data acquisition even at low mass resolving power $(\mathrm{M} / \Delta \mathrm{M} \approx 400)$, as measurements and analyses conducted at much higher mass resolution $(\mathrm{M} / \Delta \mathrm{M} \approx 8500)$ delivered essentially identical results.

Keywords Stable isotopes $\cdot$ Zinc $\cdot$ Biological reference materials $\cdot$ Double spike $\cdot$ Multiple collector inductively coupled plasma mass spectrometry $\cdot$ Ion exchange chromatography

\section{Introduction}

Zinc is an essential biological trace metal as a constituent of hundreds of enzymes with important functions in neurotransmission and for maintaining healthy immune and reproductive systems [1-4]. Disturbances in $\mathrm{Zn}$ balance have been linked directly to a number of biological disorders. Tissue $\mathrm{Zn}$ mass fractions, hereafter simply referred to as $\mathrm{Zn}$ 'concentrations', are commonly measured to investigate where and how $\mathrm{Zn}$ metabolism varies and whether new early diagnostic tools may be developed to combat diseases associated with such variations [2, 5-15].

A more sensitive way to investigate the metabolism of essential metals is to measure both the metal concentration and stable isotope composition. Such analyses on animal [16-20] and human [21-44] tissue are best performed using multiple collector inductively coupled plasma mass spectrometry (MC-ICP-MS) [45]. With such instruments, it is possible to determine isotope ratios with a precision that is at least an order of magnitude better compared to quadrupole or single collector ICP-MS. This enables the identification of smaller differences in isotope compositions, which in turn can help to identify even very small anomalies in metal metabolism. Despite this, MC-ICP-MS is currently not routinely used in 
bio-medical research. This may primarily reflect the unfamiliarity of medical researchers with the instrumentation and methods required for high precision isotope analyses and/or the comparatively high cost of the required instruments. In addition, the throughput of methods that are presently in use is severely limited by the time-consuming manual sample preparation, which is required for separation of the analyte element at high yield and purity prior to isotopic analysis $[46,47]$. The emergence of new techniques to automate and accelerate sample processing [37], however, will help to further establish the value of precise stable isotope measurements for bio-medical investigations.

Laboratories that conduct such research would benefit from the availability of biological materials with well-characterised stable isotope compositions for quality control of analyses, documentation of data quality, and to aid method development and validation. Here, we present high precision $\mathrm{Zn}$ isotope data for six commercially available biological reference material (RM) which are certified for concentrations of $\mathrm{Zn}$ and other elements [48-53]. The isotopic data were obtained in multiple analyses over a 9-month period. For comparison, an overview of stable $\mathrm{Zn}$ isotope compositions for biological materials is also provided. As well as assessing the suitability of these RMs as quality control samples for isotopic research, this study also scrutinised various analytical aspects of current techniques, including material digestion, metal isolation, choice of double spike to sample ratio [54] and MC-ICP-MS mass resolution.

\section{Materials and methods}

\section{Samples and reagents}

Sample preparation was performed in ISO Class 6 metal-free environments with Class 4 laminar flow hoods in the Imperial College London MAGIC Laboratories. AnalaR grade $6 \mathrm{M}$ $\mathrm{HCl}$ and $15.4 \mathrm{M} \mathrm{HNO}_{3}$ purified in a Teflon still, $>18 \mathrm{M} \Omega$ $\mathrm{cm} \mathrm{H}_{2} \mathrm{O}$ and $30-32 \%$ Romil $\mathrm{H}_{2} \mathrm{O}_{2}$ were used throughout. Pre-cleaned Savillex Teflon vials were employed for sample storage throughout all preparation and measurement stages, in order to minimise $\mathrm{Zn}$ blanks.

The materials chosen for $\mathrm{Zn}$ isotope characterisation were concentration certified, powdered and freeze-dried materials from the Institute of Reference Materials and Measurement (IRMM): ERM-DB001 (human hair), ERM-BB422 (fish (pollock) muscle), ERM-BB184 (bovine muscle) and ERMBB186 (pig kidney). Also analysed were two batches of Sigma Aldrich BCR-639 (human blood serum), which were stored at $-40{ }^{\circ} \mathrm{C}$, and a single batch of concentration certified, freeze-dried Seronorm Trace Elements Urine L-1. The latter RM is distributed in glass vials that contain the dried urine, which is dissolved in $5 \mathrm{ml} \mathrm{H}_{2} \mathrm{O}$ to give certified element concentrations.

The $\mathrm{Zn}$ isotope compositions of the samples were determined and are reported relative to a solution of IRMM-3702 $\mathrm{Zn}$, whilst London $\mathrm{Zn}$ and JMC Lyon $\mathrm{Zn}$ solutions were analysed as secondary reference materials. All samples and standard solutions were doped with a ${ }^{64} \mathrm{Zn}-{ }^{67} \mathrm{Zn}$ double spike solution. This highly enriched tracer is characterised by ${ }^{64} \mathrm{Zn} /{ }^{67} \mathrm{Zn} \approx 2.5$ whilst all other $\mathrm{Zn}$ isotopes contribute only about 3\% to the total $\mathrm{Zn}$ budget [55].

\section{Sample digestion}

The powdered IRMM RMs were sampled either four or five times (for pig kidney ERM-BB186), to obtain individual aliquots of between 40 and $60 \mathrm{mg}$ or $200 \mathrm{mg}$. Four $250 \mu \mathrm{l}$ samples were taken from each batch of human blood serum BCR-639. For the urine, after transferring two of the powder aliquots into Teflon vials and dissolving in $5 \mathrm{ml} \mathrm{H}_{2} \mathrm{O}$, five $2 \mathrm{ml}$ urine samples were used: two from each diluted aliquot and one mixture of the remaining $1 \mathrm{ml}$ of both. All digests were weighed using a 0.01 -mg sensitivity balance.

The samples were broken down by microwave digestion using an Ethos EZ oven, fitted with SK-10 High Pressure Rotor, in acid-cleaned $100 \mathrm{ml}$ Teflon vessels. A blank was included with each set of digestions. A 3:2 mixture of 15.4 $\mathrm{M} \mathrm{HNO}_{3}$ and $\mathrm{H}_{2} \mathrm{O}_{2}$ was added to each sample to a total of $7 \mathrm{ml}$ for Urine L-1 and $8 \mathrm{ml}$ for all other samples. After $12 \mathrm{~h}$, allowing for partial digestion, the vessels were placed in the microwave oven, which was ramped up to a temperature of $210{ }^{\circ} \mathrm{C}$ and held there for $90 \mathrm{~min}$. Following cooling, the sample digests were transferred into Savillex Teflon vials and evaporated to dryness. The hair samples were not fully digested with this method, and an organic residue remained after drying. Full digestion was subsequently achieved by the addition of $15.4 \mathrm{M} \mathrm{HNO}_{3}$ and refluxing at $160{ }^{\circ} \mathrm{C}$ for $12 \mathrm{~h}$.

\section{Double spiking}

Following evaporation, each digest was dissolved in $2 \mathrm{M} \mathrm{HCl}$ to make stock solutions with $\sim 1 \mu \mathrm{g} / \mathrm{ml} \mathrm{Zn}$ (based on the certified concentrations) and aliquots with either $\sim 250$ or $\sim 800 \mathrm{ng} \mathrm{Zn}$ were taken from each. An amount of double spike solution was then added to each aliquot to yield a molar ratio of tracer-derived to natural $\mathrm{Zn}(\mathrm{S} / \mathrm{N})$ of $1 \pm 0.05$. The resulting solutions were dried, redissolved in $6 \mathrm{M} \mathrm{HCl}$, left at $130{ }^{\circ} \mathrm{C}$ overnight to allow the sample and double spike to equilibrate, and dried again. In addition to this, various London $\mathrm{Zn}$ samples were prepared with $\mathrm{S} / \mathrm{N}$ ratios ranging from $\sim 0.75$ to $\sim 1.25$, to assess the sensitivity of the double spike data reduction to changes in spike to sample ratios. Double spiked solutions of the pure $\mathrm{Zn}$ RMs IRMM-3702 Zn, London $\mathrm{Zn}$ and JMC Lyon $\mathrm{Zn}$ with $\mathrm{S} / \mathrm{N} \approx 1$ were prepared in a similar manner. 


\section{Zinc separation}

The double spiked samples were redissolved in $1 \mathrm{M} \mathrm{HCl}$ and processed through an established anion exchange chromatography procedure $[55,56]$ to isolate $\mathrm{Zn}$ from the sample matrix. In brief, in-house shrink-fit Teflon columns with resin bed diameters of $3.5 \mathrm{~mm}$ were loaded with $250 \mu \mathrm{l}$ pre-cleaned BioRad AG MP1 100-200 mesh resin. Before sample loading, the resin was cleaned with $2 \mathrm{ml} 0.1 \mathrm{M} \mathrm{HNO}_{3}$ and $2 \mathrm{ml} \mathrm{H}_{2} \mathrm{O}$, conditioned with $3 \mathrm{ml}$ $6 \mathrm{M} \mathrm{HCl}$ and equilibrated using four aliquots of $0.5 \mathrm{ml}$ $1 \mathrm{M} \mathrm{HCl}$. The samples were loaded onto the resin in $1 \mathrm{ml}$ $1 \mathrm{M} \mathrm{HCl}$. Matrix elements were first removed using $8 \mathrm{ml}$ $1 \mathrm{M} \mathrm{HCl}$ and the $\mathrm{Zn}$ was then eluted in $6 \mathrm{ml} 0.01 \mathrm{M} \mathrm{HCl}$ for collection in Teflon vials. After drying, $50 \mu 115.4 \mathrm{M}$ $\mathrm{HNO}_{3}$ was twice added to each sample and evaporated to dryness, to remove chloride ions and convert the samples into nitrate form for isotope analysis. A London $\mathrm{Zn}$ solution was also processed through the ion exchange procedure with each batch of samples for quality control.

\section{Mass spectrometry}

Zinc stable isotope compositions were determined at the Imperial College London MAGIC Laboratory using a $\mathrm{Nu}$ Plasma HR MC-ICP-MS and an Aridus II (CETAC Technologies) sample introduction system fitted with glass nebulisers that had typical solution uptake rates of $\sim 100 \mu \mathrm{l} /$ min. Faraday collectors L3, Ax, H2 and H4 were used to measure the ion beams of ${ }^{64} \mathrm{Zn},{ }^{66} \mathrm{Zn},{ }^{67} \mathrm{Zn}$ and ${ }^{68} \mathrm{Zn}$, respectively, whilst ${ }^{62} \mathrm{Ni}$ and ${ }^{135} \mathrm{Ba}^{2+}$ (at mass 67.5 ) were monitored on collectors L5 and H3 to enable corrections for spectral interferences from isobaric $\mathrm{Ni}$ and doubly charged $\mathrm{Ba}$ ions on $\mathrm{Zn}$ isotopes. All collectors were fitted with $10^{11} \Omega$ resistors. Each sample measurement consisted of three blocks of twenty $5 \mathrm{~s}$ integration cycles. Electronic baselines were measured for $15 \mathrm{~s}$ prior to each block whilst the ion beam was deflected in the electrostatic analyser.

Both low and medium mass resolution were used to measure the $\mathrm{Zn}$ isotope ratios of the RMs. Sample and reference material solutions were prepared with $0.1 \mathrm{M} \mathrm{HNO}_{3}$ to $\mathrm{Zn}$ concentrations of $100 \mathrm{ng} / \mathrm{ml}$ or $400 \mathrm{ng} / \mathrm{g}$ for measurements at low and medium mass resolution, respectively. At low mass resolution with $\mathrm{M} / \Delta \mathrm{M} \approx 400$ (where $\Delta \mathrm{M}$ is the peak width between 5 and $95 \%$ of full peak height), the sensitivity of the instrument was typically $\sim 120 \mathrm{~V} / \mathrm{ppm}$, for a transmission efficiency of $\sim 0.05 \%$. A medium mass resolution with $\mathrm{M} / \Delta \mathrm{M} \approx 8500$ was achieved by adjusting the source defining slit. At such conditions, the sensitivity was typically $\sim 17 \mathrm{~V} /$ ppm, which translates to a much lower transmission efficiency of $\sim 0.007 \%$.

The $\mathrm{Zn}$ isotope compositions are reported as $\delta^{66 / 64} \mathrm{Zn}$, expressed in parts per thousand (\%o), which was calculated by finding the relative difference between the ${ }^{66} \mathrm{Zn} /{ }^{64} \mathrm{Zn}$ ratios of the sample and a standard (Eq. 1):

$\delta^{66 / 64} \mathrm{Zn}=\left[\left(\frac{\left(66_{\mathrm{Zn}} / 64_{\mathrm{Zn}}\right)_{\text {Sample }}}{\left(66_{\mathrm{Zn}} / 64_{\mathrm{Zn}}\right)_{\text {Standard }}}\right)-1\right] \times 1000$

Here, IRMM-3702 Zn was used as the $\delta=0$ standard for all reference material analyses and runs of IRMM-3702 Zn bracketed all sample measurements to enable close monitoring of any drift in instrumental mass bias. The standards solutions that were used for the determination of $\delta^{66 / 64} \mathrm{Zn}$ values thereby featured $\mathrm{S} / \mathrm{N}$ values and $\mathrm{Zn}$ concentrations, which matched the respective samples within 5 and $10 \%$, respectively. Following acquisition of the 'raw' isotopic data, all further data reduction, including instrumental mass bias correction via the double spike $[55,57]$, corrections for the spectral interferences from $\mathrm{Ni}^{+}$and $\mathrm{Ba}^{2+}$ ions, and calculation of the final $\delta^{66 / 64} \mathrm{Zn}$ values for samples, were carried out offline using an iterative procedure [56, 57]. For quality control, two samples of London $\mathrm{Zn}$ were processed and analysed with each batch of RMs, one with anion exchange chromatography and one without, and their $\delta^{66 / 64} \mathrm{Zn}$ offsets from IRMM-3702 $\mathrm{Zn}$ were monitored. The $\mathrm{Zn}$ concentrations were calculated offline based on the isotope dilution technique using the ${ }^{66} \mathrm{Zn} /{ }^{68} \mathrm{Zn}$ ratios determined for the sample-spike mixtures in the isotopic runs, following correction for instrumental mass fractionation.

\section{Results and discussion}

\section{Evaluation of sample preparation procedures}

A number of tests were conducted to ascertain the reliability of the sample preparation techniques used in this study for the precise determination of stable $\mathrm{Zn}$ isotope compositions. Total procedural Zn blanks ranged between 1 and $6 \mathrm{ng}(n=8)$. Such amounts are essentially negligible, as even the maximum blank would alter the $\delta^{66 / 64} \mathrm{Zn}$ value of a $250-\mathrm{ng} \mathrm{Zn}$ sample by less than $0.02 \%$, assuming an isotopic offset of $1 \%$ o between blank and sample.

The yield of the anion exchange separation protocol was determined by comparing the expected and observed $\mathrm{Zn}$ ion beam intensities during the isotopic measurements and found to be $>90 \%$ consistently for both the biological RMs and London $\mathrm{Zn}$ solutions. In addition, analyses of London $\mathrm{Zn}$ samples that were processed by anion exchange chromatography yielded $\delta^{66 / 64} \mathrm{Zn}$ values that were identical to unprocessed London $\mathrm{Zn}$ solutions (Table 1), thereby demonstrating that accurate results are achieved even if the chemical yields are $<100 \%$.

The acquisition of accurate results is further supported by the very low levels of spectral interferences from $\mathrm{Ni}$ and $\mathrm{Ba}$ isotopes, as monitored during analyses of the biological 
Table $1 \mathrm{Zn}$ isotope compositions of pure $\mathrm{Zn}$ reference materials, relative to IRMM-3702 Zn

\begin{tabular}{lllllll}
\hline Reference material & Reference & $\delta^{66 / 64} \mathrm{Zn}(\%)$ & $2 \mathrm{sd}$ & 2 se & $\mathrm{n}$ & $\mathrm{m}$ \\
\hline London Zn & This study: unprocessed & -0.22 & 0.08 & 0.04 & 4 & \\
& This study: processed & -0.20 & 0.08 & 0.03 & 8 & 5 \\
& This study: all & -0.20 & 0.07 & 0.02 & 12 & \\
& Moeller et al. 2012 [58] & -0.19 & 0.06 & 0.02 & 10 & \\
JMC Lyon & This study & -0.32 & 0.06 & 0.02 & 10 \\
& Archer et al. 2017 [59] & -0.29 & 0.09 & 0.01 & 110 \\
& Moeller et al. 2012 [58] & -0.30 & 0.05 & 0.02 & 5 \\
& Van Heghe et al. 2012 [26] & -0.30 & 0.04 & 0.01 & 24 \\
\hline
\end{tabular}

The 2sd and 2se values were calculated from repeat analyses of the RMs. The total number of measurements for each RM and the number of individual sample aliquots that were processed through separation chemistry are denoted by ' $n$ ' and ' $m$ ', respectively

${ }^{a}$ London $\mathrm{Zn}$ that was not 'processed' through the anion exchange chromatography procedure reference samples. In detail, the measurements revealed a typical contribution of $3 \mathrm{ppm}{ }^{64} \mathrm{Ni}^{+}$to the total ion beam at mass 64 and of $<1,5$ and 20 ppm for $\mathrm{Ba}^{2+}$ ions at masses 66,67 and 68 , respectively. Given these low levels, the applied interference corrections are negligible for all isotopes except ${ }^{136} \mathrm{Ba}^{2+}$, where the small correction provides accurate results that are not subject to a systematic bias.

\section{Results for pure $\mathrm{Zn}$ reference materials_London $\mathrm{Zn}$ and JMC Lyon Zn}

Individual analyses of the $\mathrm{Zn}$ standard solutions consistently produced 'internal' within-run precisions $(2 \mathrm{se})$ of about $\pm 0.05 \%$ o for $\delta^{66 / 64} \mathrm{Zn}$. The external, between-run precision (2sd), as determined from multiple analyses of both RMs, was similar or only slightly worse at about \pm 0.05 to $\pm 0.08 \%$ o (Table 1). The mean $\delta^{66 / 64} \mathrm{Zn}$ values of London $\mathrm{Zn}$ and JMC Lyon $\mathrm{Zn}$, relative to IRMM-3702 Zn, were $-0.20 \pm 0.07$ and $-0.32 \pm 0.06 \%$, respectively. These results are fully consistent with previous measurements of different aliquots of these solutions (Table 1).

London $\mathrm{Zn}$ solutions that were spiked to obtain variable $\mathrm{S} / \mathrm{N}$ values from about 0.75 to 1.25 and analysed relative to a London $\mathrm{Zn}$ solution with $\mathrm{S} / \mathrm{N} \approx 1$ revealed no clearly resolvable deviations from $\delta^{66 / 64} \mathrm{Zn}=0.00 \pm 0.06 \%$ (Fig. 1). The data, however, suggest a possible trend of decreasing $\delta^{66 /}$

${ }^{64} \mathrm{Zn}$ with increasing $\mathrm{S} / \mathrm{N}$. This trend is less apparent if the individual run results for the different $\mathrm{S} / \mathrm{N}$ ratios are plotted rather than the mean $\delta^{66 / 64} \mathrm{Zn}$ values obtained from the replicate measurements, particularly because the analytical precision is generally worse for samples with larger deviations from $\mathrm{S} / \mathrm{N}=1$ (see Electronic Supplementary Material, ESM). Given these results, samples are best analysed relative to $\delta=0$ standard solutions, which feature $\mathrm{S} / \mathrm{N}$ ratios that match to within about $15 \%$ or better (Fig. 1).

\section{Results for biological reference materials}

The $\mathrm{Zn}$ concentration and stable isotope data that were obtained for the biological RMs are summarised in Table 2 and Fig. 2, together with the certified $\mathrm{Zn}$ abundances and any reference values from previous studies.

\section{Concentration measurements}

Overall, the measured $\mathrm{Zn}$ concentrations of the biological RMs agree with the official certified values within the combined 1sd uncertainties for all samples except the pig kidney ERM-BB186 and the human urine (Trace Elements Urine L-1) (Table 2). For the pig kidney, our analyses provide a slightly higher $\mathrm{Zn}$ content of $144.5 \pm 0.7 \mu \mathrm{g} / \mathrm{g}$ compared to the certified concentration of $134 \pm 5 \mu \mathrm{g} / \mathrm{g}$. In the case of the

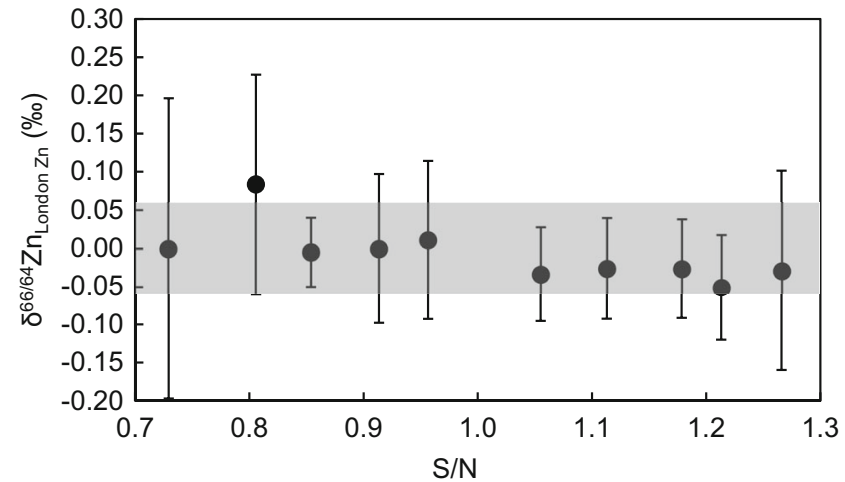

Fig. 1 Plot of $\mathrm{Zn}$ isotope compositions versus $\mathrm{S} / \mathrm{N}$ (ratio of spike-derived to natural $\mathrm{Zn}$ ) for various mixtures of the London $\mathrm{Zn}$ reference material with the $\mathrm{Zn}$ double spike. All analyses were conducted relative to a London $\mathrm{Zn}$-double spike mixture with $\mathrm{S} / \mathrm{N}=1$ over three measurement sessions and the shaded field denotes the mean external precision (2sd) of these analyses. The error bars for the individual samples show the 2 sd precision determined from multiple sample measurements $(n=2-3)$ 
Table 2 Zn concentrations and isotope compositions of six biological RMs

\begin{tabular}{|c|c|c|c|c|c|c|c|}
\hline Sample/data source & $\delta^{66 / 64} \mathrm{Zn}_{\text {IRMM- } 3702}(\%)$ & \pm 2 sd & \pm 2 se & $\mathrm{n}$ & $\mathrm{m}$ & {$[\mathrm{Zn}] \pm 1 \mathrm{sd}(\mu \mathrm{g} / \mathrm{g})$} & Digest weight (mg) \\
\hline \multicolumn{8}{|c|}{ ERM-BB422-fish muscle } \\
\hline Digest 1 & -0.37 & 0.08 & & 2 & 1 & 16.7 & 62 \\
\hline Digest 2 & -0.32 & 0.08 & & 2 & 1 & 15.9 & 196 \\
\hline Digest 3 & -0.33 & 0.07 & & 2 & 1 & 15.4 & 230 \\
\hline Digest 4 & -0.33 & 0.07 & & 2 & 2 & 16.2 & 212 \\
\hline Mean & -0.34 & 0.04 & 0.01 & 8 & 5 & $16.0 \pm 0.5$ & \\
\hline Certificate [50] & & & & & & $16.0 \pm 1.1$ & \\
\hline \multicolumn{8}{|c|}{ ERM-BB184 bovine muscle } \\
\hline Digest 1 & -0.36 & 0.08 & & 4 & 2 & 152.0 & 66 \\
\hline Digest 2 & -0.31 & 0.07 & & 2 & 2 & 151.0 & 63 \\
\hline Digest 3 & -0.23 & 0.08 & & 4 & 2 & 151.3 & 213 \\
\hline Digest 4 & -0.29 & 0.06 & & 4 & 2 & 152.6 & 243 \\
\hline Mean & -0.30 & 0.10 & 0.03 & 14 & 8 & $151.5 \pm 0.4$ & \\
\hline Reference [22] & -0.24 & 0.02 & & & & & \\
\hline Certificate [48] & & & & & & $146 \pm 7.0$ & \\
\hline \multicolumn{8}{|c|}{ ERM-BB186 - pig kidney } \\
\hline Digest 1 & -0.73 & 0.07 & & 2 & 2 & 144.0 & 42 \\
\hline Digest 2 & -0.69 & 0.08 & & 4 & 3 & 144.0 & 56 \\
\hline Digest 3 & -0.63 & 0.08 & & 2 & 1 & 144.9 & 195 \\
\hline Digest 4 & -0.66 & 0.08 & & 2 & 1 & 145.2 & 218 \\
\hline Digest 5 & -0.55 & 0.08 & & 2 & 1 & 144.6 & 204 \\
\hline Mean & -0.65 & 0.13 & 0.04 & 12 & 8 & $144.5 \pm 0.7$ & \\
\hline Certificate [49] & & & & & & $134 \pm 5$ & \\
\hline \multicolumn{8}{|c|}{ ERM-DB001—human hair } \\
\hline Digest 1 & -0.33 & 0.07 & & 3 & 2 & 197.4 & 53 \\
\hline Digest 2 & -0.32 & 0.07 & & 3 & 2 & 201.9 & 43 \\
\hline Digest 3 & -0.32 & 0.07 & & 3 & 2 & 203.2 & 238 \\
\hline Digest 4 & -0.28 & 0.07 & & 3 & 2 & 211.8 & 204 \\
\hline Mean & -0.31 & 0.04 & 0.01 & 12 & 8 & $203.6 \pm 5.9$ & \\
\hline Certificate [52] & & & & & & $209 \pm 12.0$ & \\
\hline \multicolumn{8}{|c|}{ Trace elements urine - $-\mathrm{L}-1$} \\
\hline Digest 1 —vial 1 & -0.05 & 0.07 & & 3 & 2 & 0.216 & 2020 \\
\hline Digest 2 -vial 1 & -0.06 & 0.11 & & 2 & 2 & 0.233 & 1997 \\
\hline Digest 3-vial 2 & -0.05 & 0.02 & & 2 & 2 & 0.214 & 1870 \\
\hline Digest 4 -vial 2 & -0.07 & 0.06 & & 1 & 2 & 0.218 & 2018 \\
\hline Digest 5-vial $1 \& 2$ & -0.03 & 0.06 & & 1 & 1 & 0.221 & 1995 \\
\hline Mean & -0.05 & 0.03 & 0.01 & 9 & 9 & $0.221 \pm 0.008$ & \\
\hline Certificate [53] & & & & & & $0.347 \pm 0.035$ & \\
\hline \multicolumn{8}{|c|}{ BCR-639-human blood serum } \\
\hline Digest 1 - batch 1 & -3.25 & 0.08 & & 2 & 1 & 2.43 & 242 \\
\hline Digest 2-batch 1 & -3.34 & 0.08 & & 2 & 1 & 2.55 & 250 \\
\hline Digest 3-batch 1 & -3.39 & 0.08 & & 1 & 1 & 2.43 & 250 \\
\hline Digest 4 -batch 1 & -3.27 & 0.08 & & 1 & 1 & 2.27 & 246 \\
\hline Digest 5-batch 2 & -3.22 & 0.08 & & 1 & 1 & 2.43 & 245 \\
\hline Digest 6-batch 2 & -3.24 & 0.08 & & 1 & 1 & 2.53 & 248 \\
\hline Digest 7—batch 2 & -3.33 & 0.10 & & 1 & 1 & 2.37 & 266 \\
\hline Digest 8 - batch 2 & -3.32 & 0.10 & & 1 & 1 & 2.29 & 227 \\
\hline Mean & -3.29 & 0.12 & 0.04 & 10 & 8 & $2.41 \pm 0.10$ & \\
\hline Reference [21] & -3.06 & 0.20 & & & & & \\
\hline Certificate [51] & & & & & & $2.36 \pm 0.14$ & \\
\hline
\end{tabular}

The 2sd data for the $\delta^{66 / 64} \mathrm{Zn}$ values of individual digest are based on repeat analyses of the matching standard, whereas the $2 \mathrm{sd}$ and $2 \mathrm{se}$ for the mean $\delta^{66 /}$

${ }^{64} \mathrm{Zn}$ values of each RM (italicised) are calculated from all individual RM measurements. The total number of measurements and the number of individual sample aliquots that went through the separation chemistry for each digest and RM are denoted by 'n' and 'm', respectively

urine, we find a significant deviation from the certified $\mathrm{Zn}$ concentration, with a result of $221 \pm 8 \mathrm{ng} / \mathrm{g}$ versus a reference value of $347 \pm 70 \mathrm{ng} / \mathrm{g}$. It is improbable that this difference is primarily due to incomplete transfer of the sample powder from the glass storage vials prior to initial sample dissolution in $5 \mathrm{ml} \mathrm{H} \mathrm{H}_{2} \mathrm{O}$ (the volume at which the $\mathrm{Zn}$ concentration is certified [53]). This is reinforced by the observation that essentially identical $\mathrm{Zn}$ concentrations were measured for two different glass vials of the urine RM even though the amount of dry residue recovered from each vial differed slightly (at 


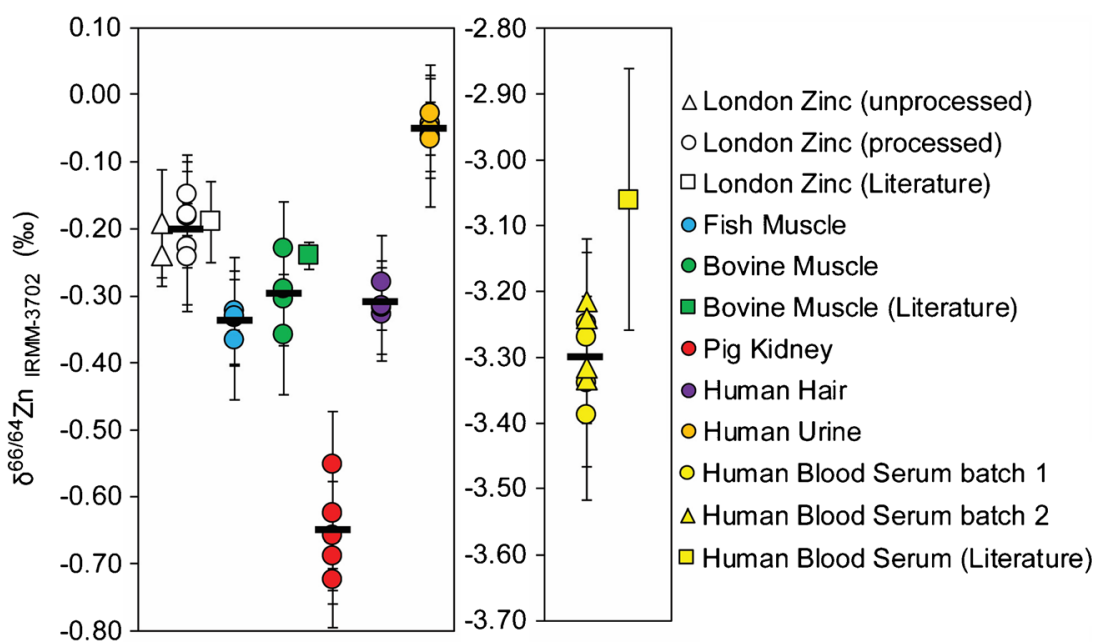

Fig. 2 Zinc isotope composition measured for individual digests of the RMs. Each data point denotes the mean of at least two samples from the same digest and error bars show the 2 sd precision calculated from the individual measurements. The two different London $\mathrm{Zn}$ data points from this study represent samples that were 'processed' through our anion exchange chromatography procedure and those that were not

136.36 and $126.43 \mathrm{mg})$. Hence, it is more likely that the low $\mathrm{Zn}$ concentration determined here reflects either sample heterogeneity amongst different aliquots or batches of the urine $\mathrm{RM}$ or a high $\mathrm{Zn}$ blank during the original certification measurements.

\section{Isotope analysis}

For the isotopic analyses of the biological RMs, the internal precision was similar to results obtained for pure $\mathrm{Zn}$ solutions at about $\pm 0.05 \%$ o (2se) for $\delta^{66 / 64} \mathrm{Zn}$. A similar result emerges for the external reproducibility of data obtained for single digests of the biological RMs that were analysed multiple times and where some digests were split into two or three aliquots for separate processing through the column chemistry (Table 2). In detail, these measurements yielded precisions ( $2 \mathrm{sd}$ ) of \pm 0.04 to $\pm 0.10 \%$, nearly identical to the reproducibility seen for multiple London $\mathrm{Zn}$ and JMC Lyon $\mathrm{Zn}$ analyses (Table 1). Together, these results demonstrate that the separation procedure produces clean $\mathrm{Zn}$ cuts, which enable precise isotopic analyses that are not affected by spectral or nonspectral interferences.

The accuracy of the $\mathrm{Zn}$ stable isotope data can be evaluated, as reference values from previous studies are available for two of the materials, bovine muscle ERM-BB184 and human blood serum BCR-639 (Table 2, Fig. 2). For the bovine muscle, our $\delta^{66 / 64} \mathrm{Zn}$ result of $-0.30 \pm 0.10 \%$ agrees with data from a different laboratory $(-0.24 \pm 0.02 \%$ o [22]). For BCR639 , the average $\delta^{66 / 64} \mathrm{Zn}$ value found was $-3.29 \pm 0.12 \%$, with no difference between the two batches $(-3.31 \pm 0.13$ and $3.28 \pm 0.11 \%$ ). The $\delta^{66 / 64} \mathrm{Zn}$ value of this sample is identical to previous analyses of the RM, which were conducted (unprocessed). For the human blood serum, the results are plotted on a different $y$-axis, due to the large isotopic offset. The $\delta^{66 / 64} \mathrm{Zn}$ literature data for London $\mathrm{Zn}$, bovine muscle and human blood serum are from Moeller et al. 2012 [58], Costas-Rodríguez et al. 2014 [22] and Larner et al. 2015 [21], respectively

by a different analyst on a separately purchased batch of the material [21]. Notably, these latter measurements yielded a comparatively large uncertainty of $\pm 0.2 \%$ (Table 2 ).

The $\delta^{66 / 64} \mathrm{Zn}$ data that were obtained for the remaining four reference materials showed only limited variability, with results of $-0.34 \pm 0.04 \%$ o for fish muscle ERM-BB422, -0.65 $\pm 0.13 \%$ o for pig kidney ERM-BB186, $-0.31 \pm 0.04 \%$ o for human hair ERM-DB001 and $-0.05 \pm 0.04 \%$ or the Seronorm Trace Elements Urine L-1 (Table 2, Fig. 2). Notably, the dried residue in two glass vials of the urine RM produced solutions with identical $\mathrm{Zn}$ isotope compositions. The latter result suggests that the urine RM is likely to have a homogeneous $\mathrm{Zn}$ isotope composition despite possible significant differences in Zn concentration.

The isotopic analyses for four of the biological RMs were carried out both at low and medium mass resolutions to better ascertain the accuracy of the data. The results for the different analysis modes are compared in Fig. 3. Importantly, this diagram reveals no significant differences between these two sets of data. This indicates that our sample preparation procedure produces $\mathrm{Zn}$ solutions, which are sufficiently pure for accurate $\delta^{66 / 64} \mathrm{Zn}$ measurements even at low mass resolution. Importantly, this allows for more repeat analyses of individual samples or smaller sample size, as much less $\mathrm{Zn}$ is needed for a single measurement at low mass resolution than at medium mass resolution, where ion beam transmission is much lower. This may prove important in bio-medical studies because tissue sample size is often limited and sampling is usually only possible on a single occasion.

The overall mean values that were calculated for the six biological RMs are based on at least eight individual analyses, which were obtained on four to eight separate digests. 
Fig. 3 Average $\delta^{66 / 64} \mathrm{Zn}$ values of RMs obtained in

measurements at low and medium mass resolution ( $L M R$ and $M M R)$.

Each data point is the mean of six to eight individual measurements and error bars represent the $2 \mathrm{sd}$ precision

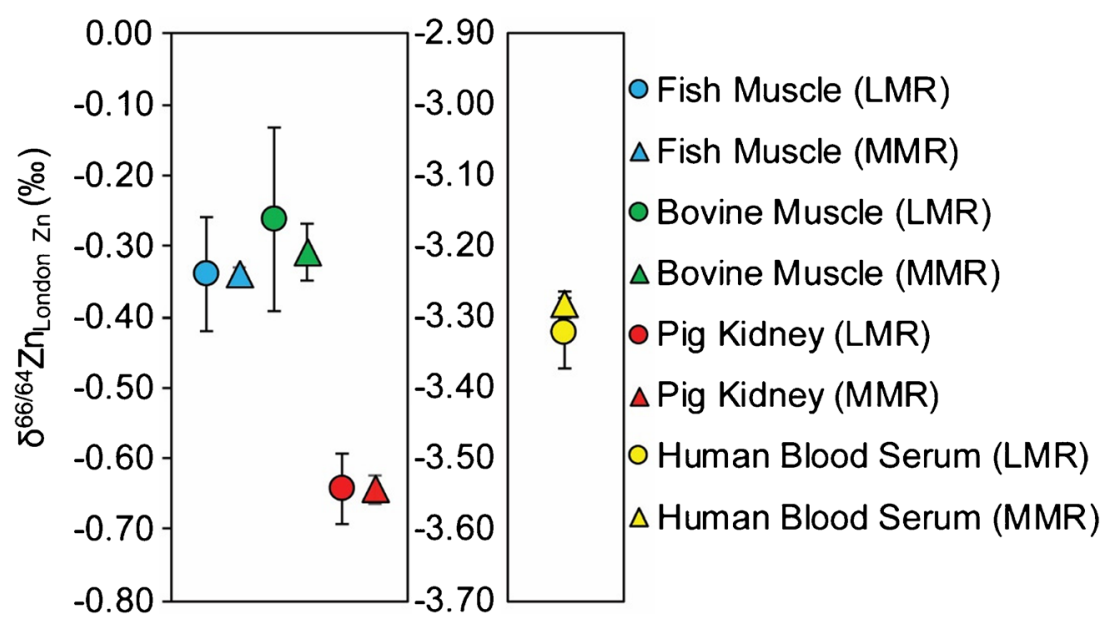

Notably, the 2 sd uncertainties of the mean results vary between \pm 0.04 and $\pm 0.13 \%$ o (Table 2). In detail, three of the biological RMs reveal overall mean results with uncertainties of $\geq 0.10 \%$ and which are hence slightly but noticeably larger than the typical 2sd reproducibilities for multiple measurements of a single digest (generally $\leq 0.08 \%$ o). It is possible that this small discrepancy reflects minor sample heterogeneities, which are just noticeable when sampling occurs at the 50 to $200 \mathrm{mg}$ scale. However, given the current uncertainty of stable $\mathrm{Zn}$ isotope analyses of about \pm 0.05 to $\pm 0.15 \%$ o (2sd), this slight heterogeneity will have only a minor impact on any results.

Also of note is the observation that all but one of the biological RMs have $\delta^{66 / 64} \mathrm{Zn}$ values of between about \pm 0.0 and $0.8 \%$ and which hence fall within the range of stable isotope compositions that were previously measured for such tissues (Fig. 4). As such, they are particularly well-suited as quality control materials for $\mathrm{Zn}$ isotope analyses. The exception is BCR-639, which is about $3 \%$ o lower in $\delta^{66 / 64} \mathrm{Zn}$ compared to previous results obtained for human blood and blood serum (Fig. 4). This large discrepancy is most likely related to the preparation of this RM, which involved the addition of a $\mathrm{Zn}$ solution (NIST SRM 3168a) to natural blood serum [63]. It is also conceivable that this method of preparation may be responsible for the possible minor isotopic heterogeneity of this sample, as is indicted by the relatively poor reproducibility of our overall mean result and the comparatively large difference between the data obtained here and previously by Larner et al. [21].

\section{Conclusions}

A double spike technique in conjunction with MC-ICP-MS was used to measure the $\mathrm{Zn}$ isotope compositions of six biological reference materials with certified trace metal concentrations. It is shown that these methods are suitable for the

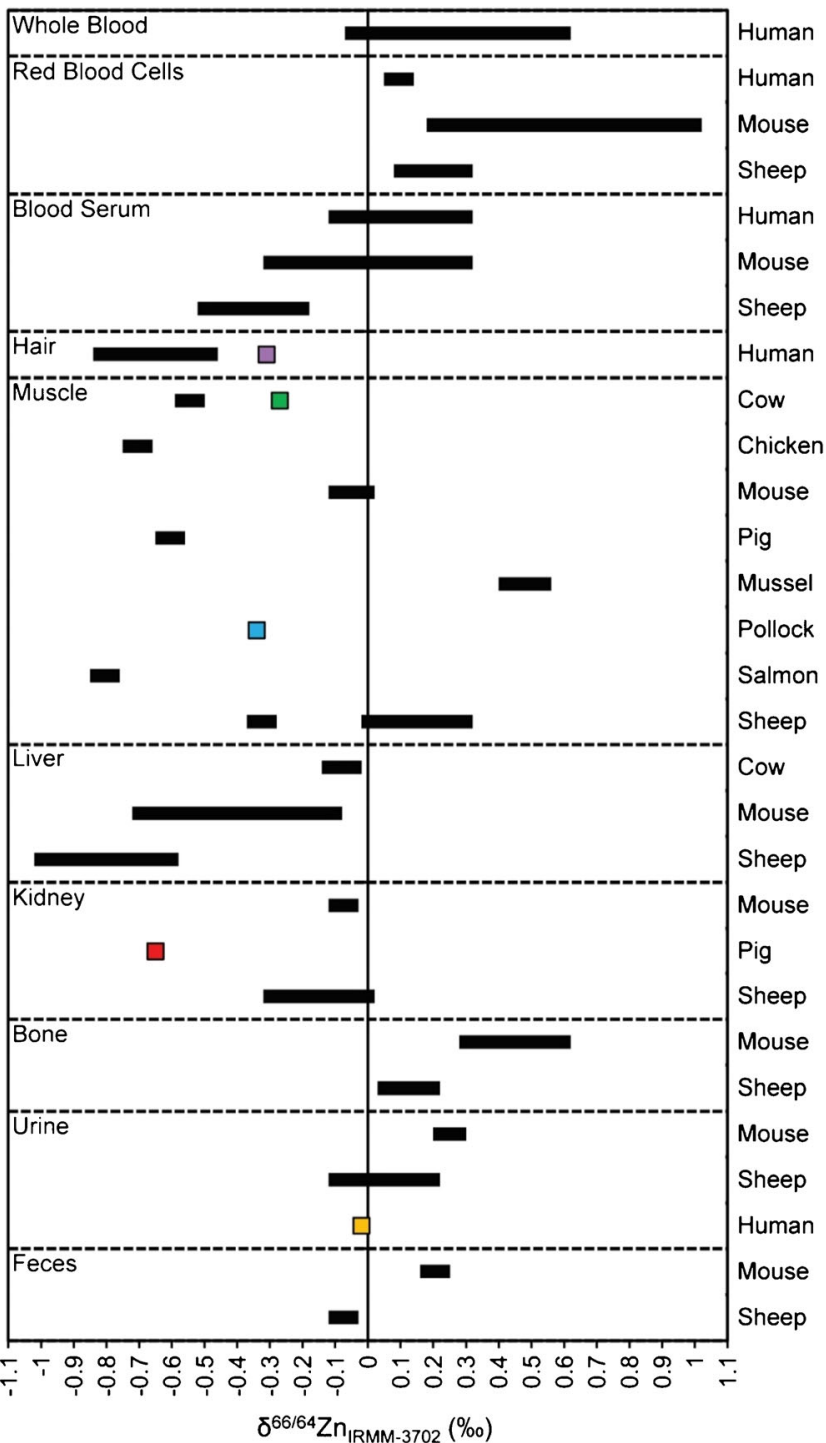

Fig. 4 Compilation of published $\delta^{66 / 64} \mathrm{Zn}$ values for animal tissue and the reference materials analysed in this study (squares, except BCR-639), reported relative to IRMM-3702 $\mathrm{Zn}$ [16, 18, 21, 22, 25, 26, 29, 60-62]. Literature data reported relative to JMC Lyon $\mathrm{Zn}$ was corrected for an offset of $0.32 \%$ o between IRMM-3702 Zn and JMC Lyon Zn (Table 1) 
routine determination of $\delta^{66 / 64} \mathrm{Zn}$ with an external precision (2sd) of about \pm 0.05 to $\pm 0.10 \%$. Analyses of multiple digests of the biological RMs yielded mean $\delta^{66 / 64} \mathrm{Zn}$ values with a reproducibility of between \pm 0.04 and $\pm 0.13 \%$. This suggests that these RMs feature no or only very minor heterogeneities in $\mathrm{Zn}$ isotope composition, when sampling occurs on the scale of 50 to $200 \mathrm{mg}$. As such, all are in principle ideally suited as quality control materials for $\mathrm{Zn}$ isotope measurements in biomedical research. This conclusion is reinforced by the observations that all samples, except for human blood serum BCR639 , also have $\mathrm{Zn}$ isotope compositions that fall within the range of normal natural values. The unusually low $\delta^{66 / 64} \mathrm{Zn}$ value of BCR-639 reflects that this sample was produced by the addition of a purified $\mathrm{Zn}$ solution to natural blood and this non-natural origin may limit the suitability of this material for some applications. Further measurements revealed that isotopic analyses of the samples at low and medium mass resolution produced essentially identical $\mathrm{Zn}$ isotope data. This demonstrates that the sample preparation procedure yields sufficiently pure separates of $\mathrm{Zn}$, such that the isotopic measurements do not require medium mass resolution to resolve remaining spectral interferences. This result is advantageous, as low mass resolution analyses require significantly less $\mathrm{Zn}$ than measurements at higher mass resolving power.

Acknowledgements This project was funded by a Janet Watson Scholarship awarded to RETM and an STFC Impact Acceleration Award to MR.

\section{Compliance with ethical standards}

Conflict of interest The authors declare that they have no conflicts of interest.

Open Access This article is distributed under the terms of the Creative Commons Attribution 4.0 International License (http:// creativecommons.org/licenses/by/4.0/), which permits unrestricted use, distribution, and reproduction in any medium, provided you give appropriate credit to the original author(s) and the source, provide a link to the Creative Commons license, and indicate if changes were made.

\section{References}

1. Bonaventura P, Benedetti G, Albarède F, Miossec P. Zinc and its role in immunity and inflammation. Autoimmun Rev. 2015;14: 277-85. doi:10.1016/j.autrev.2014.11.008.

2. Tapiero H, Tew KD. Trace elements in human physiology and pathology: zinc and metallothioneins. Biomed Pharmacother. 2003;57:399-411. doi:10.1016/S0753-3322(03)00081-7.

3. Pluhator MM, Thomson ABR, Fedorak RN. Clinical aspects of trace elements: zinc in human nutrition-zinc deficiency and toxicity. Can J Gastroenterol. 1996;10:97-103.

4. Haase H, Rink L. Multiple impacts of zinc on immune function. Metallomics. 2014;6:1175. doi:10.1039/c3mt00353a.

5. Aranha LN, Lobo JC, Stockler-Pinto MB, Leal VDO, Torres JPM, Mafra D. Relationship between zinc levels and plasma leptin in hemodialysis patients. J Trace Elem Med Biol. 2012;26:238-42. doi:10.1016/j.jtemb.2012.02.007.

6. Panayi AE, Spyrou NM, Iversen BS, White MA, Part P. Determination of cadmium and zinc in Alzheimer's brain tissue using inductively coupled plasma mass spectrometry. J Neurol Sci. 2002;195:1-10. doi:10.1016/S0022-510X(01)00672-4.

7. Zhao H-W, Lin J, Wang X-B, Cheng X, Wang J-Y, Hu B-L, et al. Assessing plasma levels of selenium, copper, iron and zinc in patients of parkinson's disease. PLoS One. 2013;8:e83060. doi:10. 1371/journal.pone.0083060.

8. Prasad AS. Impact of the discovery of human zinc deficiency on health. J Trace Elem Med Biol. 2014;28:357-63. doi:10.1016/j. jtemb.2014.09.002.

9. Kozlowski H, Luczkowski M, Remelli M, Valensin D. Copper, zinc and iron in neurodegenerative diseases (Alzheimer's, Parkinson's and prion diseases). Coord Chem Rev. 2012;256:2129-41. doi:10. 1016/j.ccr.2012.03.013.

10. Bjorklund G. The role of zinc and copper in autism spectrum disorders. Acta Neurobiol Exp (Wars). 2013;73:225-36.

11. Kawahara M, Mizuno D, Koyama H, Konoha K, Ohkawara S, Sadakane Y. Disruption of zinc homeostasis and the pathogenesis of senile dementia. Metallomics. 2014;6:209-19. doi:10.1039/ C3MT00257H.

12. Damphousse V, Mailhot M, Berthiaume Y, Rabasa-Lhoret R, Mailhot G. Plasma zinc in adults with cystic fibrosis: correlations with clinical outcomes. J Trace Elem Med Biol. 2014;28:60-4. doi: 10.1016/j.jtemb.2013.10.003.

13. Stelmashook EV, Isaev NK, Genrikhs EE, Amelkina GA, Khaspekov LG, Skrebitsky VG, et al. Role of zinc and copper ions in the pathogenetic mechanisms of Alzheimer's and Parkinson's diseases. Biochem Biokhimiia. 2014;79:391-6. doi:10.1134/ S0006297914050022.

14. González-Domínguez R, García-Barrera T, Gómez-Ariza JL. Characterization of metal profiles in serum during the progression of Alzheimer's disease. Metallomics. 2014;6:292-300. doi:10. 1039/c3mt00301a.

15. Chiba M, Katayama K, Takeda R, Morita R, Iwahashi K, Onishi Y, et al. Diuretics aggravate zinc deficiency in patients with liver cirrhosis by increasing zinc excretion in urine. Hepatol Res. 2013;43: 365-73. doi:10.1111/j.1872-034X.2012.01093.x.

16. Balter V, Lamboux A, Zazzo A, Télouk P, Leverrier Y, Marvel J, et al. Contrasting $\mathrm{Cu}, \mathrm{Fe}$, and $\mathrm{Zn}$ isotopic patterns in organs and body fluids of mice and sheep, with emphasis on cellular fractionation. Metallomics. 2013;5:1470. doi:10.1039/c3mt00151b.

17. Balter V, Zazzo A, Moloney AP, Moynier F, Schmidt O, Monahan FJ, et al. Bodily variability of zinc natural isotope abundances in sheep. Rapid Commun Mass Spectrom. 2010;24:605-12. doi:10. 1002/rcm.4425.

18. Moynier F, Fujii T, Shaw AS, Le Borgne M. Heterogeneous distribution of natural zinc isotopes in mice. Metallomics. 2013;5:693. doi:10.1039/c3mt00008g.

19. Büchl A, Hawkesworth CJ, Ragnarsdottir KV, Brown DR. Repartitioning of $\mathrm{Cu}$ and $\mathrm{Zn}$ isotopes by modified protein expression. Geochem Trans. 2008;9:11. doi:10.1186/1467-4866-9-11.

20. Hirata T, Tanoshima M, Suga A, Tanaka Y, Nagata Y, Shinohara A, et al. Isotopic analysis of calcium in blood plasma and bone from mouse samples by multiple collector-ICP-mass spectrometry. Anal Sci. 2008;24:1501-7.

21. Larner F, Woodley LN, Shousha S, Moyes A, Humphreys-Williams E, Strekopytov S, et al. Zinc isotopic compositions of breast cancer tissue. Metallomics. 2015;7:112-7. doi:10.1039/C4MT00260A.

22. Costas-Rodríguez M, Van Heghe L, Vanhaecke F. Evidence for a possible dietary effect on the isotopic composition of $\mathrm{Zn}$ in blood via isotopic analysis of food products by multi-collector ICP-mass spectrometry. Metallomics. 2014;6:139-46. doi:10.1039/ C3MT00244F. 
23. Gulson B, Wong H, Korsch M, Gomez L, Casey P, McCall M, et al. Comparison of dermal absorption of zinc from different sunscreen formulations and differing UV exposure based on stable isotope tracing. Sci Total Environ. 2012;420:313-8. doi:10.1016/j. scitotenv.2011.12.046.

24. Jaouen K, Pons M-L, Balter V. Iron, copper and zinc isotopic fractionation up mammal trophic chains. Earth Planet Sci Lett. 2013;374:164-72. doi:10.1016/j.eps1.2013.05.037.

25. Van Heghe L, Deltombe O, Delanghe J, Depypere H, Vanhaecke F. The influence of menstrual blood loss and age on the isotopic composition of $\mathrm{Cu}, \mathrm{Fe}$ and $\mathrm{Zn}$ in human whole blood. J Anal At Spectrom. 2014;29:478-82. doi:10.1039/C3JA50269D.

26. Van Heghe L, Engström E, Rodushkin I, Cloquet C, Vanhaecke F. Isotopic analysis of the metabolically relevant transition metals $\mathrm{Cu}$, $\mathrm{Fe}$ and $\mathrm{Zn}$ in human blood from vegetarians and omnivores using multi-collector ICP-mass spectrometry. J Anal At Spectrom. 2012;27:1327. doi:10.1039/c2ja30070b.

27. Télouk P, Puisieux A, Fujii T, Balter V, Bondanese VP, Morel A-P, et al. Copper isotope effect in serum of cancer patients. A pilot study. Metallomics. 2015;7:299-308. doi:10.1039/C4MT00269E.

28. Costas-Rodríguez M, Anoshkina Y, Lauwens S, Van Vlierberghe $\mathrm{H}$, Delanghe J, Vanhaecke F. Isotopic analysis of $\mathrm{Cu}$ in blood serum by multi-collector ICP-mass spectrometry: a new approach for the diagnosis and prognosis of liver cirrhosis? Metallomics. 2015;7: 491-8. doi:10.1039/C4MT00319E.

29. Jaouen K, Gibert M, Lamboux A, Telouk P, Fourel F, Albarède F, et al. Is aging recorded in blood $\mathrm{Cu}$ and $\mathrm{Zn}$ isotope compositions? Metallomics. 2013;5:1016-24. doi:10.1039/C3MT00085K.

30. Larner F, Sampson B, Rehkämper M, Weiss DJ, Dainty JR, O'Riordan S, et al. High precision isotope measurements reveal poor control of copper metabolism in Parkinsonism. Metallomics. 2013;5:125. doi:10.1039/c3mt20238k.

31. Aramendía M, Rello L, Resano M, Vanhaecke F. Isotopic analysis of $\mathrm{Cu}$ in serum samples for diagnosis of Wilson's disease: a pilot study. J Anal At Spectrom. 2013;28:675. doi:10.1039/c3ja30349g.

32. Resano M, Aramendía M, Rello L, Calvo ML, Bérail S, Pécheyran C. Direct determination of $\mathrm{Cu}$ isotope ratios in dried urine spots by means of fs-LA-MC-ICPMS. Potential to diagnose Wilson's disease. J Anal At Spectrom. 2013;28:98-106. doi:10.1039/ C2JA30262D.

33. Balter V, Nogueira da Costa A, Bondanese VP, Jaouen K, Lamboux A, Sangrajrang $S$, et al. Natural variations of copper and sulfur stable isotopes in blood of hepatocellular carcinoma patients. Proc Natl Acad Sci. 2015;112:982-5. doi:10.1073/pnas.1415151112.

34. Jaouen $\mathrm{K}$, Balter V. Menopause effect on blood $\mathrm{Fe}$ and $\mathrm{Cu}$ isotope compositions. Am J Phys Anthropol. 2014;153:280-5. doi:10. 1002/ajpa.22430.

35. Jaouen K, Balter V, Herrscher E, Lamboux A, Telouk P, Albarède F. $\mathrm{Fe}$ and $\mathrm{Cu}$ stable isotopes in archeological human bones and their relationship to sex. Am J Phys Anthropol. 2012;148:334-40. doi: 10.1002/ajpa.22053.

36. Albarède F, Telouk P, Lamboux A, Jaouen K, Balter V. Isotopic evidence of unaccounted for $\mathrm{Fe}$ and $\mathrm{Cu}$ erythropoietic pathways. Metallomics. 2011;3:926. doi:10.1039/c1mt00025j.

37. Anoshkina Y, Costas-Rodríguez M, Vanhaecke F. High-precision $\mathrm{Fe}$ isotopic analysis of whole blood for biomedical purposes without prior isolation of the target element. J Anal At Spectrom. 2015;30:1816-21. doi:10.1039/C5JA00209E.

38. von Blanckenburg F, Oelze M, Schmid DG, van Zuilen K, Gschwind H-P, Slade AJ, et al. An iron stable isotope comparison between human erythrocytes and plasma. Metallomics. 2014;6: 2052-61. doi:10.1039/C4MT00124A.

39. Hotz K, Walczyk T. Natural iron isotopic composition of blood is an indicator of dietary iron absorption efficiency in humans. JBIC J Biol Inorg Chem. 2013;18:1-7. doi:10.1007/s00775-012-0943-7.
40. Van Heghe L, Delanghe J, Van Vlierberghe H, Vanhaecke F. The relationship between the iron isotopic composition of human whole blood and iron status parameters. Metallomics. 2013;5:1503. doi: $10.1039 / \mathrm{c} 3 \mathrm{mt} 00054 \mathrm{k}$.

41. von Blanckenburg F, Noordmann J, Guelke-Stelling M. The iron stable isotope fingerprint of the human diet. J Agric Food Chem. 2013;61:11893-9. doi:10.1021/jf402358n.

42. Hotz K, Krayenbuehl P-A, Walczyk T. Mobilization of storage iron is reflected in the iron isotopic composition of blood in humans. JBIC J Biol Inorg Chem. 2012;17:301-9. doi:10.1007/s00775-0110851-2.

43. Krayenbuehl P-A. Hereditary hemochromatosis is reflected in the iron isotope composition of blood. Blood. 2005;105:3812-6. doi: 10.1182/blood-2004-07-2807.

44. Morgan JLL, Skulan JL, Gordon GW, Romaniello SJ, Smith SM, Anbar AD. Rapidly assessing changes in bone mineral balance using natural stable calcium isotopes. Proc Natl Acad Sci. 2012;109:9989-94. doi:10.1073/pnas.1119587109.

45. Rehkämper M, Schönbächler M, Stirling $\mathrm{CH}$. Multiple collector ICP-MS: introduction to instrumentation, measurement techniques and analytical capabilities. Geostand Newsl. 2001;25:23-40. doi: 10.1111/j.1751-908X.2001.tb00785.x.

46. Archer C, Vance D. Mass discrimination correction in multiplecollector plasma source mass spectrometry: an example using $\mathrm{Cu}$ and $\mathrm{Zn}$ isotopes. J Anal At Spectrom. 2004;19:656. doi:10.1039/ b315853e.

47. Mason TFD, Weiss DJ, Horstwood M, Parrish RR, Russell SS, Mullane E, et al. High-precision $\mathrm{Cu}$ and $\mathrm{Zn}$ isotope analysis by plasma source mass spectrometry. J Anal At Spectrom. 2004;19: 209. doi:10.1039/b306958c.

48. Institute for Reference Materials and Measurements (IRMM) (2005) Certificate of analysis ERM-BB184. https://ec.europa.eu/ jrc/sites/default/files/rm/ERM-BB184_cert.pdf

49. (IRMM) I for RM and M (2005) Certificate of analysis ERMBB186. https://ec.europa.eu/jrc/sites/default/files/rm/ERMBB186_cert.pdf

50. Institute for Reference Materials and Measurements (IRMM) (2005) Certificate of analysis ERM-BB422. http://www.erm-crm. org/ERM products/search/certificates/BB422.pdf

51. Institute for Reference Materials and Measurements (IRMM) (2007) Certified Reference Material BCR-639. https://ec.europa. eu/jrc/sites/default/files/rm/BCR-639_cert.pdf

52. Institute for Reference Materials and Measurements (IRMM) (2013) Certificate of Analysis ERM-DB001. https://ec.europa.eu/ $\mathrm{jrc} / \mathrm{sites} /$ default/files/rm/ERM-DB001_cert.pdf

53. Seronorm (2015) Seronorm ${ }^{\mathrm{TM}}$ Trace Elements Urine L-1, Lot 1403080

54. Rudge JF, Reynolds BC, Bourdon B. The double spike toolbox. Chem Geol. 2009;265:420-31. doi:10.1016/j.chemgeo.2009.05. 010 .

55. Arnold T, Schönbächler M, Rehkämper M, Dong S, Zhao F-J, Kirk GJD, et al. Measurement of zinc stable isotope ratios in biogeochemical matrices by double-spike MC-ICPMS and determination of the isotope ratio pool available for plants from soil. Anal Bioanal Chem. 2010;398:3115-25. doi:10.1007/s00216-010-4231-5.

56. Bridgestock LJ, Williams H, Rehkämper M, Larner F, Giscard MD, Hammond S, et al. Unlocking the zinc isotope systematics of iron meteorites. Earth Planet Sci Lett. 2014;400:153-64. doi:10.1016/j. eps1.2014.05.029.

57. Siebert C, Nägler TF, Kramers JD. Determination of molybdenum isotope fractionation by double-spike multicollector inductively coupled plasma mass spectrometry. Geochemistry Geophys Geosystems. 2001;2:1032-16. doi:10.1029/2000GC000124.

58. Moeller K, Schoenberg R, Pedersen R-B, Weiss D, Dong S. Calibration of the new certified reference materials ERM-AE633 and ERM-AE647 for copper and IRMM-3702 for zinc isotope 
amount ratio determinations. Geostand Geoanalytical Res. 2012;36:177-99. doi:10.1111/j.1751-908X.2011.00153.x.

59. Archer C, Andersen MB, Cloquet C, Conway TM, Dong S, Ellwood $\mathrm{M}$, et al. Inter-calibration of a proposed new primary reference standard AA-ETH Zn for zinc isotopic analysis. J Anal At Spectrom. 2017;226:280-97. doi:10.1039/C6JA00282J.

60. Stenberg A, Andrén H, Malinovsky D, Engström E, Rodushkin I, Baxter DC. Isotopic variations of $\mathrm{Zn}$ in biological materials. Anal Chem. 2004;76:3971-8. doi:10.1021/ac049698f.

61. Ohno T, Shinohara A, Chiba M, Hirata T. Precise Zn isotopic ratio measurements of human red blood cell and hair samples by multiple
collector-ICP-mass spectrometry. Anal Sci. 2005;21:425-8. doi:10. 2116/analsci.21.425.

62. Maréchal CN, Télouk P, Albarède F. Precise analysis of copper and zinc isotopic compositions by plasma-source mass spectrometry. Chem Geol. 1999;156:251-73. doi:10.1016/S0009-2541(98) 00191-0.

63. Byrialsen K, Kristiansen J, Christensen JM, Dirscherl C, Gawlik BM, Klein CL, Lamberty A (2004) The certification of the mass concentrations of aluminium, selenium and zinc in human serum (BCR-637, BCR-638, BCR-639). Inst. Ref. Mater. Meas. 